\title{
Efficacy of Omalizumab therapy in a case of severe atopic dermatitis
}

\author{
Jonathan Lacombe Barrios ${ }^{1,2^{*}}$, Louis Paradis ${ }^{1}$, Anne Desroches ${ }^{2}$ \\ From Canadian Society of Allergy and Clinical Immunology Annual Scientific Meeting 2011 \\ Quebec, Canada. 20-23 October 2011
}

\section{Background}

Atopic dermatitis (AD) is a common skin disease of childhood which may cause debilitating symptoms and greatly impair the quality of life of the patient and his relatives [1]. Treatment of chronic AD usually focuses on topical regimen of emolients and immunosuppressants, although systemic immunosuppressive therapy is sometimes required in more severe cases. Omalizumab is a humanized monoclonal anti- IgE antibody that binds at the high-affinity receptor (FceRI) binding site that has revealed some potential in the treatment of severe and recalcitrant $\mathrm{AD}[2]$.

\section{Case}

Here, we present the case of a 11-years-old girl who has been under treatment with Omalizumab for the past five years. The patient first presented at 2 months of age with a global and severe AD involving. She was severely atopic with total IgE levels of 121,000, mild asthma, and multiple food allergies. Treatment with oral prednisone, cyclosporin, azathioprine and intravenous immunoglobulins did not improve her skin symptoms significantly. She was hospitalised multiple times for skin infections attributed to the disease and immunosuppressive medication. Treatment with Omalizumab was initiated at 6 years of age. Four months later, SCORAD index improved significantly. Since, her follow-up has been almost free of any remarkable event and treatment with Omalizumab has been well tolerated.

\section{Conclusion}

Omalizumab should be considered as a potential treatment in cases of severe $\mathrm{AD}$ resistant to classical therapy.

${ }^{1}$ Centre Hospitalier de I'Université de Montréal, Department of Medicine, Service of allergy and clinical immunology, Montreal, Canada

Full list of author information is available at the end of the article

\section{Author details}

'Centre Hospitalier de I'Université de Montréal, Department of Medicine, Service of allergy and clinical immunology, Montreal, Canada. ${ }^{2}$ Centre Hospitalier Universitaire Sainte-Justine, Departement of paediatrics, Service of allergy and clinical immunology, Montreal, Canada.

Published: 14 November 2011

\section{References}

1. Chamlin SL, Chren MM: Quality-of-life outcomes and measurement in childhood atopic dermatitis. Immunol Allergy Clin North Am 2010, 30(3):281-288

2. Boguniewicz Mark, Schmid-Grendelmeier Peter, Leung YM Donald: Atopic dermatitis. J Allergy Clin Immunol 2006, 118(1):40-43.

\section{doi:10.1186/1710-1492-7-S2-A33}

Cite this article as: Barrios et al:: Efficacy of Omalizumab therapy in a case of severe atopic dermatitis. Allergy, Asthma \& Clinical Immunology 2011 7(Suppl 2):A33.

Submit your next manuscript to BioMed Central and take full advantage of:

- Convenient online submission

- Thorough peer review

- No space constraints or color figure charges

- Immediate publication on acceptance

- Inclusion in PubMed, CAS, Scopus and Google Scholar

- Research which is freely available for redistribution

\section{Biomed Central}

(c) 2011 Barrios et al; licensee BioMed Central Ltd. This is an open access article distributed under the terms of the Creative Commons Attribution License (http://creativecommons.org/licenses/by/2.0), which permits unrestricted use, distribution, and reproduction in any medium, provided the original work is properly cited. 